\title{
Adding Entrepreneurship to India's Science, Technology \& Innovation Policy
}

\author{
Ragini Chaurasia ${ }^{* 1}$, Mitrasen Bhikajee ${ }^{2}$
}

\begin{abstract}
Science, Technology \& Innovation Policy (STIP) is an important policy instrument particularly in the developing countries. India also has recognized the role of science, technology and innovation in development as early as 1958 but still trails behind its peer Brazil, China and the Asian tiger Singapore. Considering strong correlation between research and development investment and growth based on existing studies, this paper brings forth the present situation of India in investment and its influence on the performance of the economy vis-à-vis the three countries. This paper studies the STIP 2013 in detail and reports the contribution of the Department of Science and Technology in India. The main conclusion of this paper is the recommendation for incorporation of "entrepreneurship" in STIP based on global best practices, which can be achieved by government's involvement as a venture capitalist to seed and support innovations, increasing transparency and incorporating entrepreneurial curriculum.
\end{abstract}

Keywords: entrepreneurial policy and education; growth; India; private sector; government as venture capital; STIP

Submitted: January $25^{\text {th }} 2016 /$ Approved: June $7^{\text {th }} 2016$

\section{Introduction}

Economic development theories identify scientific innovation, research and development as promising factor of economic growth. Historically economists and policy advisors have undertaken numerous researches to establish the relationship between science and technology (S\&T) and economic growth. Works of Romer (1986) and Lucas (1988) are the examples of these researches in the past. They have brought forward the hypothesis that the advancement in S\&T will be most important promoting factor to achieve economic growth and social development. In the next paragraph, we have done a similar analysis based on data on Singapore.

Table 1 shows the correlation matrix for GDP per capita, and S\&T indicators of Singapore between 1996 and 2012. The S\&T indicators used are number of researchers, number of journal publications and research and development (R\&D) expenditure as percent of GDP. These indicators serve as suitable proxies for measuring S\&T (Zhang et al., 2012). Based on Pearson's $r$ correlation rule, we observe that number of researchers and publications of journals is very strongly positively related with $\mathrm{R} \& \mathrm{D}$ expenditure and so is the GDP per capita with number of researchers and publications of journals. We also observe that the GDP per capita is strongly positively related with R\&D expenditure.

These positive correlations indicate a possibility that increased R\&D investment increases the performance of S\&T indicators, which in turn boosts the economy. Similarly, the increased performance of S\&T indicators and better economic conditions can again increase R\&D as a feedback effect. Thus, S\&T promotes economic performance of a country and the economic performance further boosts scientific innovation.

Indeed research by Zhang et al. (2012) proved a long-term equilibrium relationship between scientific innovation and economic growth for Beijing using a Vector Autoregressive Model on indicators for S\&T outputs and GDP. He argues that this presence of an interactivity means that scientific innovation promotes economic growth and economic growth boosts the scientific innovation. Similar study in Spain by Sanchez-Sellero et al (2015) show that R\&D activities (especially external R\&D activities) improve the productivity of Spanish manufacturing firms as empirical evidence towards importance of investment in science technology and innovation (STI).

Table 1. Correlation matrix between GDP per capita, number of researchers, number of journal publications and R\&D expenditure as \% of GDP

\begin{tabular}{|c|c|c|c|c|}
\hline Correlation & GDP per capita & Nos. journal pub. & Nos. researchers & $\mathrm{R} \& \mathrm{D}$ (\% of GDP) \\
\hline GDP per capita & 1.0000 & & & \\
\hline Nos. journal pub. & 0.8093 & 1.0000 & & \\
\hline R\&D (\% of GDP) & 0.5110 & 0.8471 & 0.8402 & 1.0000 \\
\hline
\end{tabular}

Source: Analysis on World Bank Data

(1) Sciences Po - Economics Department - Paris, France.

(2) UNESCO New Delhi, India.

${ }^{*}$ Corresponding author: ragini.chaurasia@sciencespo.fr 
Such understandings have created a wave of STIP across the developed and developing countries. For example, India has declared 201020 as a Decade of Innovations during which it targets to raise R\&D expenditures to 2.0 percent of GDP (indefinite) by enhancing private sector participation and to position India among the top five global scientific powers while giving priorities to biotechnology, pharmaceuticals, space, nuclear, defence, ICT (software), environment and energy sectors (STIP, 2013).

Similarly Brazil and China has implemented a policy for promotion of science (OECD, 2015). Brazil aims to raise financial resources for innovation, by raising $\mathrm{R} \& \mathrm{D}$ national total expenditure to 1.8 percent of GDP and firms R\&D expenditure to 0.9 percent of GDP by 2014 . It also aims to increase the number of innovative firms from 41243 in 2008 to 65000 in 2014 and to increase the number of firms that conduct continuous R\&D from 3425 in 2008 to 5000 in 2014 by expanding and strengthening infrastructure for S\&T research and by increasing the support to human resources capacity building in strategic fields, especially the engineering sciences. China plans to increase R\&D investment to 2.5 percent of GDP by 2020; and place China in the world top five positions in patenting and international citations.

While STIPs are implemented differently in each country, it is a big contributor in economic growth and more refinement is required to STIP. This paper is an attempt to study the performance of India economic growth, STI investment and improvements in health in comparison to its peer Brazil and China and one of the Asian tiger Singapore. Among India, China and Brazil, Brazil has specified targeted action plans in its policy documents. All of the three nations focus to place themselves highly in terms of scientific capabilities. China has the highest target for investment in R\&D. India has defined broader objectives in its STIP; more specifications are required to meet its objectives.

Similar studies on STIP evaluation exist in the literature. These papers discusses aspects on intention of creation of a national innovation system (NIS) (Dayasindhu et al. 2005); competitive pressure as a source to private sector R\&D (Salami et al 2012); NIS as an important determinant of economic performance (Reddy 1997); India's stand as country with high number of science-intensive sectors (Ratchford et al. 2008); India's central position for multinational companies R\&D investment (Salami et al 2012) and India's failure in turning its research in profitable venture (Rongping et al. 2008). We draw information on these studies in this paper and bring a recommendation to the policy makers that entrepreneurship should be considered as the main focus in the future policy making both in terms of government's role as a venture capital to seed and promote innovation in some predefined fields and in terms of capabilities enhancement of research staffs. The paper also highlights the fact that India's performance in entrepreneurial space indicates a requirement of government intervention to boost entrepreneurial activities.

The paper also outlines the most important aspect of the STIP in India and tracks the progress made by the Department of Science and
Technology through its scheme. This section draws attention of the policy makers towards analysis of what can be a "good" investment to utilize the full capabilities of the economy. This section also discusses the rising issue on how can private sector take the onus of R\&D investment. India's STIP 2013 targets to increase the Indian R\&D investment from 0.8 percent to 2 percent and specifies an increase in private sector contribution as its main strategy in order to achieve its target. The paper dwells on the fact that there might be a stark contrast in the industry sector between the government and private. An affirmative statement in this regard cannot be made mainly because of lack of sufficient data. In addition the paper also brings forth the necessity of transparency in R\&D investment by all the stakeholders to identify the areas with highest need and greatest potential and to allow an effect policy dialogue between government and industry. Last but not the least, the paper brings to the attention of the policy makers that performance on productivity is an indication on untapped potential and as a future opportunity for the policy makers. It is our belief that entrepreneurship as a key aspect in STIP can reinforce consistent efforts in strengthening science, technology and innovation thereby helps to reach to the untapped potential.

\section{India: a comparative standing}

This section discusses the progress of the four economies - Brazil, China, India and Singapore. While China and Brazil are comparable to India because of the size of it economies and area, Singapore is the Asian pioneer in implementing successfully science and technology as a tool to foster growth and development.

Indeed in all of these economies, a lot of policies have been adopted to fasten the catch up process and among these a great share is attributed to the progress in science and technology. This section, thus, first discusses the trajectories of $\mathrm{R} \& \mathrm{D}$ investment of the four economies and then brings forth a comparative study on GDP growth (GDP per capita) and developments in health (fertility, mortality and life expectancies). Together with this productivity of the economy (total factor productivity and labour factor productivity) is also considered as a by-product of progress in R\&D. The paper discusses the concept of productivity improvement in later section of the paper.

\section{a. Expenditure on R\&D of India vis. à vis. Brazil, China, and Singapore}

We carry out an analysis on the R\&D expenditure as a percent of GDP ${ }^{1}$ (Figure 1) for the four countries over the horizon 1996 and 2013. Analysis shows that the expenditure on R\&D is highest for China, followed by Brazil, Singapore and India in the mentioned order. With a yearly-average R\&D expenditure per capita of US\$359.7, Singapore has the highest expenditure per person. This is followed by Brazil with a yearly-average expenditure per person of US\$ 69.9, China with a yearly-average expenditure per person of US\$ 44.4. India stands last among the four countries with a yearly-average expenditure per person of mere US\$ 5.8. As the difference in the yearly-average

(1) Data on R\&D expenditure is not available prior to 1996. Also for Brazil data is not available between 1996 and 2000 both years inclusive. 
expenditure is very sharp for India and rest of the three countries, we try to change the scale of analysis from $R \& D$ expenditure per capita to $\mathrm{R} \& \mathrm{D}$ expenditure per student enrolled in tertiary education. ${ }^{2}$

Considering the gross enrolment ratio in tertiary education (ISCED 5 and $6^{3}$ ) for the year 2011, the population between age group 15 to 64 years and R\&D investment in $2011^{4}$ for India, we estimated the number of people potentially enrolled in the tertiary education. We find that India has spent approximately US\$ 81 , which is still way less than one-fourth of the R\&D investment per capita by Singapore. We admit that the estimate of the R\&D investment per unit student in tertiary education may be less than actual figures because the calculation relies on the percentage of population between 15 to 64 years age group and not on the percentage of the total population of the five-year age group following on from secondary school leaving as mentioned in World Bank data source; however the main point of this estimate is primarily to provide an interpretation that even if the total $R \& D$ investment per capita is adjusted for the actual number of people with potential to enter into research studies ${ }^{5}$, India might be able to barely match the actual investment made by Singapore per unit of its total population.

The expenditure as a percent of GDP has increased in the period of observation in cumulative terms, however there is no specific trend in the growth rate pattern. This means that while most years have seen an increase in the percent expenditure there are years where the expenditure has declined for at least a few of these countries under discussion. The cumulative annual growth rate between 2001 and 2011 both years included for Brazil is 1.58 percent, for China is 1.71 percent, India is 0.73 percent and Singapore is 6.67 percent. In comparison when R\&D expenditure increased for India by 1 folds, Brazil increased their expenditure in R\&D by 2.16 folds, China by 2.33 folds whereas Singapore by 9.12 folds.

Figure 1. Comparison on Research and Development expenditure of India, Brazil, China, and Singapore

(a) Research and development expenditure as a \% of GDP

(b) Research and development expenditure per capita (US \$)
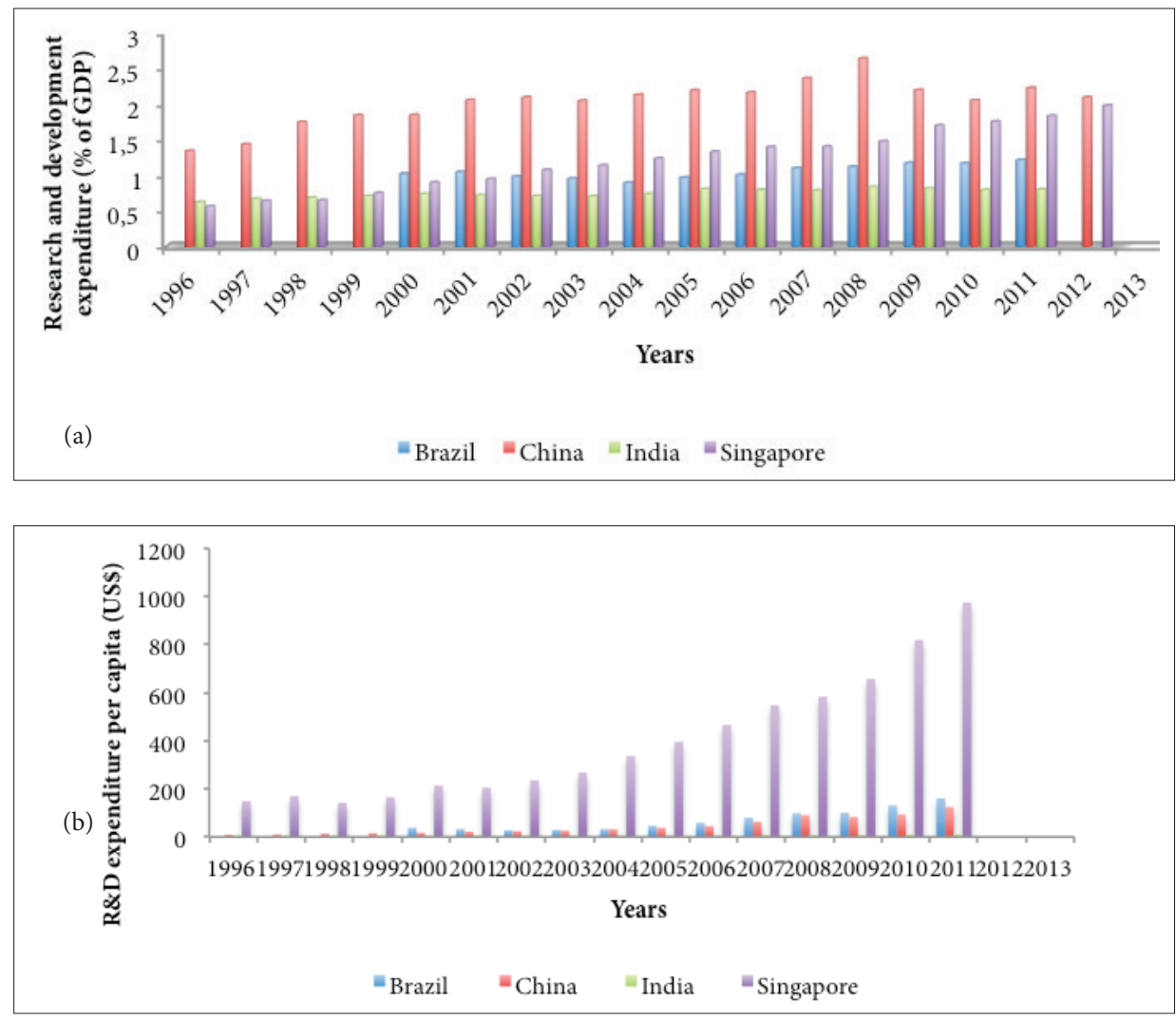

Source: Analysis on World Bank Data

(2) We do this analysis in order to take in account India's high population. Similar analysis on the rest of the country is not done to prevent loss of focus of the paper.

(3) UNESCO Institute for Statistics defines ISCED 5 as Short-cycle tertiary and ISCED 6 as Bachelor's or equivalent.

(4) Data source: World Bank

(5) A serious concern in India is also the number of students enrolling for education level ISCED 8 (the level defined as Doctoral Studies by UNESCO Institutes for Statistics). Ministry of Human Resource Development has reported that only 84505 students are enrolled in Ph.D. that is less than 0.5 percent of the total student enrolment. At PhD level, maximum number of students is enrolled in Science (22 percent) stream followed by Engineering \& Technology (20.5 percent). 


\section{b. Macro-economic data of India vis. à vis. Brazil, China, and Singapore}

On studying the GDP per capita of these countries (Figure 2 a) we find that Singapore is at the top for all the years between 1970 and 2013 (both years inclusive); followed by Brazil. China and India both started very closely, however China gradually picked up and grew far above that of India's GDP. GDP per capita has been on a rise for all these economies. Singapore and Brazil have surpassed India about 5 decades ago, while China surpassed India about 2.5 decades ago.
It is interesting to note that the Singapore and Brazil have surpassed GDP per capita of India despite a decreasing trend in the GDP growth rate for both countries (Figure $2 \mathrm{~b} \mathrm{c} \mathrm{de}$ ). At the same time, both China and India have shown an increasing trend in the GDP growth rate. Further analysis shows that a low GDP per capita is a characteristic of high population in both India and China, as both India and China have GDP higher than Singapore. Figure 2d shows that population of India is increasing steeper than China and is likely to surpass it soon. Given this scenario India needs to adopt strategies that both increases the GDP and decreases the population growth simultaneously.

Figure 2. Macro-economic comparison between India, China, Brazil and Singapore

(a) GDP per capita between 1970 and 2013 (b) GDP growth rate between 1970 and 2013 - Brazil (c) GDP growth rate between 1970 and 2013 Singapore (d) GDP growth rate between 1970 and 2013 - China (e) GDP growth rate between 1970 and 2013 India (f) GDP current US\$ between 1970 and 2013 (g) Population between 1970 and 2013
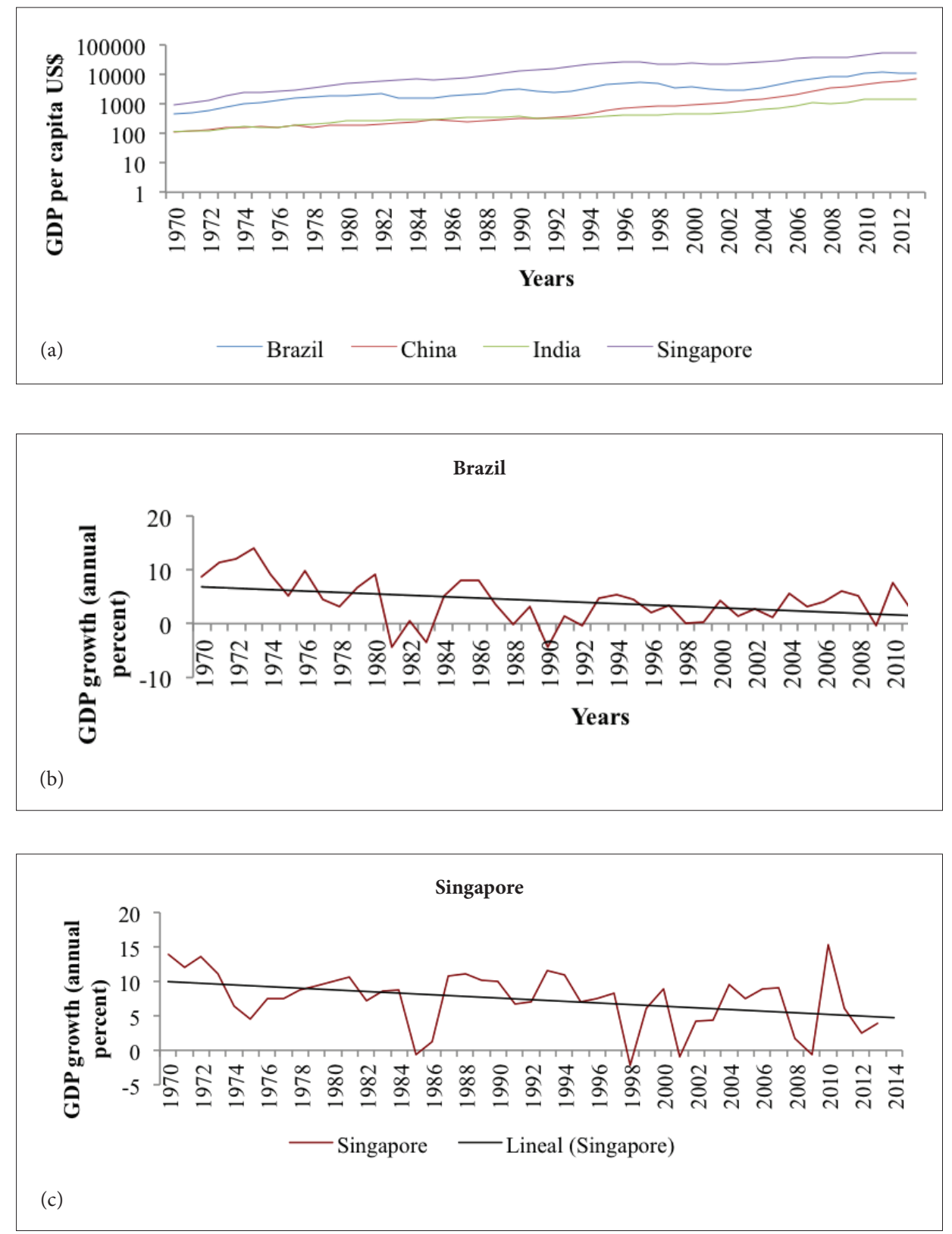

ISSN: 0718-2724. (http://jotmi.org) 

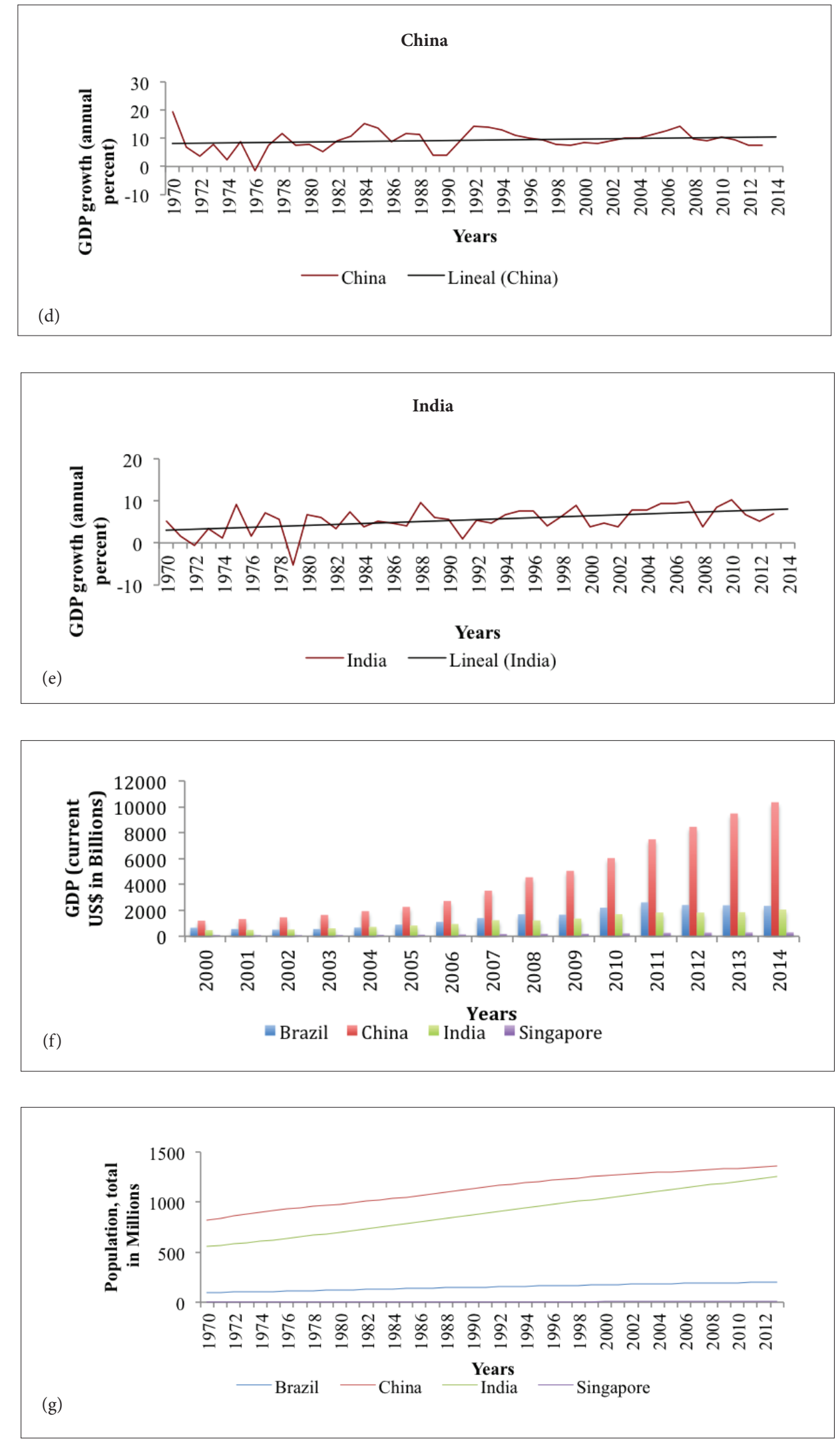

Source: Analysis on World Bank Data 


\section{c. Progress in health indicators of India vis. à vis. Brazil, China, and Singapore}

The progress in health indicators of India in comparison to Brazil, China and Singapore are presented in the Figure 3. It is interesting to note that, all these countries have seen a decline in the fertility rate and mortality rate while experiencing an increase in life expectancies, a positive signal of growth. However, among these countries, India has the highest fertility rate, highest mortality rate and lowest life expectancies at birth in all the years. In 2013, India recorded about 5 births per two women on average i.e. 20 new-borns to eight women. Out of these 20 new-borns, one dies below an age of 5 years and the remaining 19 can live on an average up to 66.45 years.

Figure 3. Health status comparison between India, China, Brazil and Singapore

a) Fertility rate, total births per woman between 1970 and 2013

b) Mortality rate, under-5 per 1000 live births between 1970 to 2013

c) Life expectancies at birth between 1970 and 2013
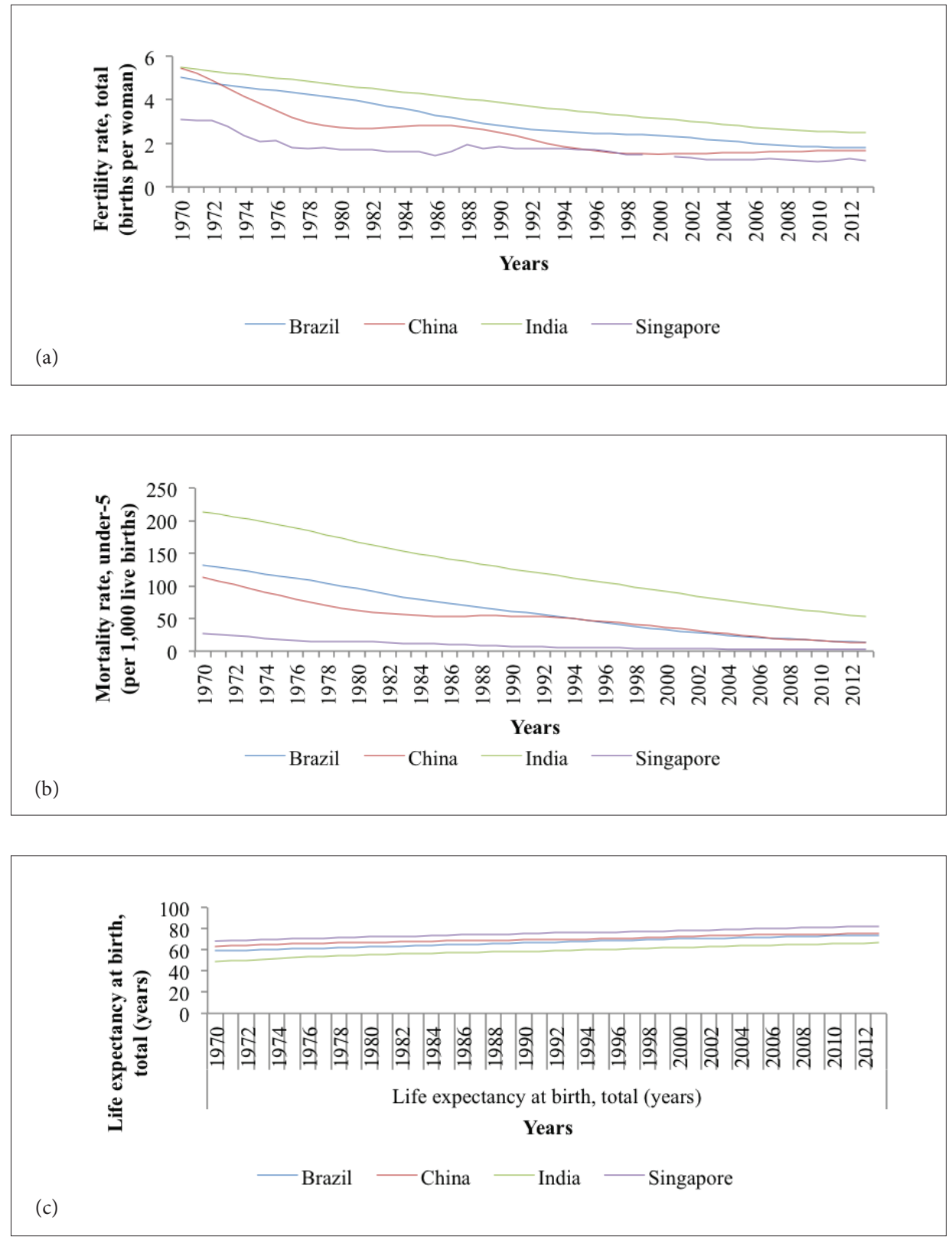

Source: Analysis on World Bank Data 
The fertility rate per women in Brazil is 1.8, China 1.6 and Singapore 1.2. Similarly, the mortality rate per thousand in Brazil is 13.7, China is 12.7 and Singapore 2.8 and the life expectancies at birth for Brazil is 73.8 years, China is 75.3 years and Singapore is 82.3 years, respectively accounting for a life expectancies which is $11 \%, 13 \%$ and $24 \%$ higher than that in India respectively. Clearly, a person born in Brazil, China and Singapore is more likely to see better health conditions than one born in India. A high population together with weaker surviving conditions of India compared to its peers brings the need for more innovative solution to improve the life of people and hence should be a focus for promoting R\&D in this direction.

A high population together with weaker surviving conditions of India compared to its peers brings the need of more innovative solution to improve the life of people and hence should be a focus for promoting $\mathrm{R} \& \mathrm{D}$ in this direction.

\section{Science Policy of India and Schemes to promote R\&D}

\section{a. Sciences, Technology and Innovation Policy of India}

STIP in India has been in existence for five decades; with its first mention in 1958 where the primary focus was on scientific research and it promotion-technology was expected to flow as a by-product of the science activities. This was followed by an adoption of Technology policy in 1983 with objectives to make India self-reliant and technologically capable. This was succeeded by a combined Science and Technology Policy in 2003, which emphasized the need for investment in R\&D. The present STIP of India was introduced in 2013 as a necessary framework to integrate Science, Technology and Innovations; it outlines the major activities that have been undertaken in the field of science in India in last few decades.

STIP 2013 identifies science, technology and innovations as a key driver for development and has given central importance to STI enterprises for growth of India. It recognizes that very little has been done in India to give due importance to innovation as an instrument for policy. With an ambition to position India among top five global scientific powers by 2020 , the Government of India (GoI) has declared the decade 2010-20 as the "Decade of Innovation" while enforcing the STIP 2013. An important aspect of the STIP 2013 is that, it promotes innovation in the select problems of society and also introduces the key features that will enable innovation to benefit all levels of the society. The detailed list of identified problems and key features of innovation as a policy tool as identified by the STIP 2013 is given
Table 2. Role of innovations as indicated in STIP 2013

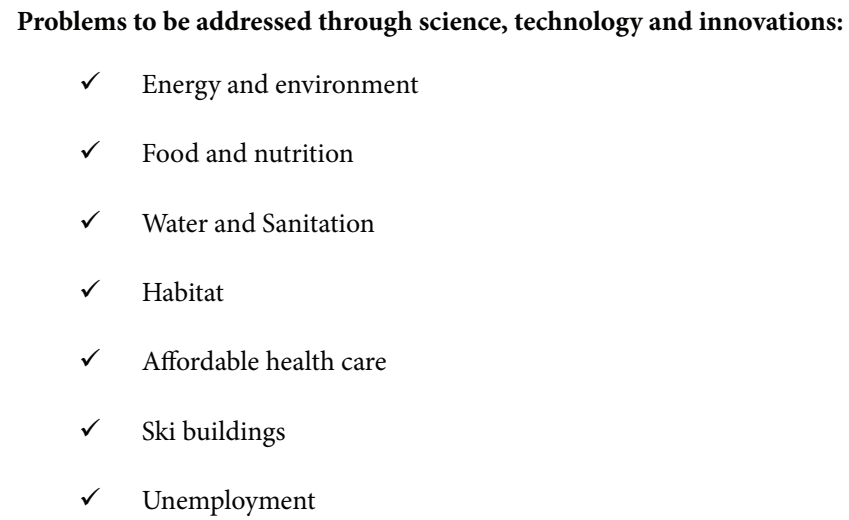

Key feature to make science, technology and innovations a change-agent:

$\checkmark$ Inclusion: innovation should be accessible, available, and affordable by large portion of the population

$\checkmark \quad$ Bridge-gaps: innovation should be able to bridge gaps between the science and technology and socio-economic needs of the country

Source: STIP 2013

STIP specifies some key objectives to improve the adoption of science and technology in India. These objectives are specified in Figure 4. To meet these objectives STIP discusses many frontiers of immediate actions, however it does not clearly specify its course of actions. These frontier actions are as follows.

$\checkmark \quad$ To enable school science education reforms by improving teaching methods, science curricula, motivating science teachers and schemes for early attraction of talent to science.

$\checkmark \quad$ To devise new and flexible schemes to address the participation and mobility challenges of employed women scientists and technologists.

$\checkmark \quad$ To create multi-disciplinary (including humanities) inter-university research centres.

$\checkmark \quad$ To create high-cost global infrastructures in some fields through international consortia models.

$\checkmark$ Create transparent centrally implementable Performance Related Incentive Scheme (PRIS) for promotion research funds. 
Figure 4. Objectives specified in STIP 2013
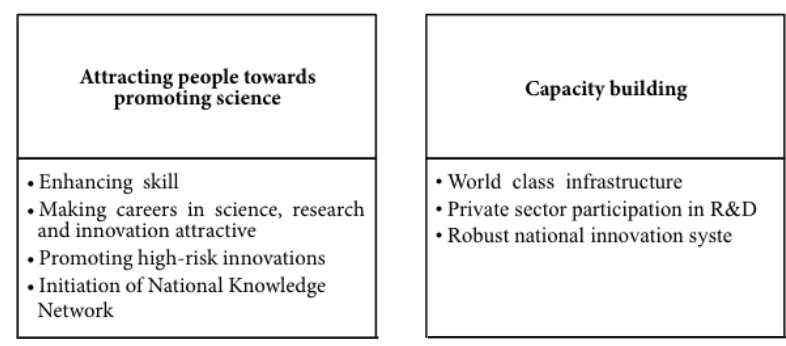

Source: STIP 2013

Target: To position India among top five global scientific powers by 2020

\section{b. Contribution of Department of Sciences and Technology to promote STIP 2013}

The GoI has recognized Science, Technology and Innovation as an important factor for fostering GDP growth for more than 4 decades (STIP, 2013). In its attempts, GoI launched Department of Science \& Technology in May 1971 with the following objectives:

$\checkmark \quad$ Formulation of policies relating to science and technology to enhance capabilities and sectorial linkages

$\checkmark \quad$ Financial support and promote R\&D (including technological surveys and at all levels state, district, and village) for

- bio-fuel production, processing, standardization and applications

- utilization of by-products to development value added chemicals. $\checkmark \quad$ Promotion of ventures involving the commercialization of such technology.

$\checkmark \quad$ Capacity building including setting-up of new institutions and institutional infrastructure.

$\checkmark$ Application of S\&T for weaker sections, women and other disadvantaged sections of society.

$\checkmark \quad$ Support S\&T entrepreneurship development.

$\checkmark$ Creation of autonomous research institutions.

$\checkmark \quad$ Creating international relations.

In order to meet these objectives a number of scientific programs are launched which are given below Figure 5.

Figure 5. Programs launched by Department of Science \& Technology

\section{Mission on Nano Science and Technology (Nano Mission) \\ Mega Facilities for Basic Research \\ Fund for Improvement of S\&T Infrastructure in Universities \& Higher Educational Institu- tions (FIST) \\ Sophisticated Analytical Instrument Facilities (SAIFs)}

Human Resource Development and Nurturing Young Talent / Swarnajayanti Fellowships

Women Scientists Programs

Kishore Vaigyanik Protsahan Yojana

Innovation in Science Pursuit for Inspired Research (INSPIRE) programme

National Science \& Technology Management Information System (NSTMIS)
Focused on Nano technology, an allocation of US\$ 167 Millions has been made for 5 years in May 2007

This facility extends grants for R\&D across institutions. No specific budget or procedure is mentioned in the website.

Same as above. However, they provide the support at three levels, which focuses on infrastructure building, quality of education and research enhancement. The budget limit varies between US\$ 170 Thousands to US\$ 1.7 Millions depending on their quality.

Similar to above. It is an infrastructure investment that has created 13 such centres across India. These centres also provide trainings and workshops to use such instruments.

Under this scheme GoI has provided financial support to doctoral students in science, engineering and medicine in the form of a modest sum of US $\$ 5000$ per person per year to an average 8 researchers per year from 1997 to 2012. This leads to a total of 95 students.

Women between age group of 30-50 years are provided three types of scholarship - for research in basic/ applied science, research in S\&T and self-employment. This scheme gives preference to women with a break in career en Scientists Program are as follows.

- For research in basic/applied science - An allowance of about US\$ 12000 is provided annually per person, which includes fellowship of the applicant and cost of small equipment, contingencies, travel, consumables etc.

- Research in S\&T - this provides support to women in two modes - internship and project mode. A special one-year internship program has been launched during $12^{\text {th }}$ year plan. The internship aims at developing a proposal for financial support, which is provided under project mode. About US $\$ 4500$ per year per person is provided under internship mode and about US $\$ 5500$ per year per person is provided under project mode.

318 fellowships have been awarded under this scheme and National Science Olympiad Programme has been launched

Launched in 2008, an investment of US $\$ 32.875$ Millions has been made for programs to attract students in early ages towards sciences, scholarships for higher education in science and assured opportunities for research careers

A total of US\$ 3 Millions has been allocated in investments have been made for collection, collation, analysis and dissemination of information 
The total investment by the Department of Science and Technology in these above-mentioned programs cannot be estimated based on these information. This is mainly because of lack of availability of data for all the individual projects and the total contributions. However, as discussed before the above reported investments have played a great role in helping India pace up its economic growth. World Bank data reports that 10669 patent applications have been filled by residents in India by 2013 and approx. 160 researchers are involved in $\mathrm{R} \& \mathrm{D}$ per million people in India by 2010. These patents and researchers are a by-product of growth of S\&T in India. In addition, technological parks have been established which are also successful in contributing their part towards creation of employment and trades across India (Vaidyanathan, 2007). One of the bigger questions still remains that whether these investments are enough to meet the potential of the country. There is a need for policy makers to focus on analysing the requirement of the country.

\section{c. STIP 2013 on private sector investment in R\&D}

The STIP 2013 has given special attention to the need for an increase in $\mathrm{R} \& \mathrm{D}$ investment from the private sector. This increase is recognized as the main tool to increase the overall $R \& D$ investment in India. The major actions proposed in the policy for immediate actions are provided in the Figure 6. For this, the policy also calls for identification of around 10 sectors of high impact potential for directed STI intervention and deployment of requisite resources. The policy also aims to target twice the global trade in high technology products (from 8 percent) and the present technological intensity of these sectors (from 6-7 percent).

Figure 6. Main tools to increase private sector investment in India
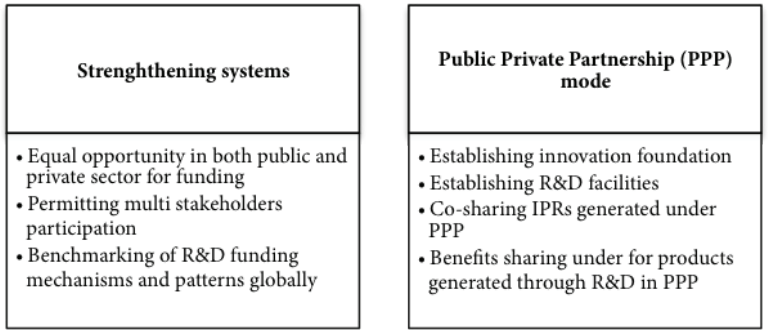

Source: STIP 2013

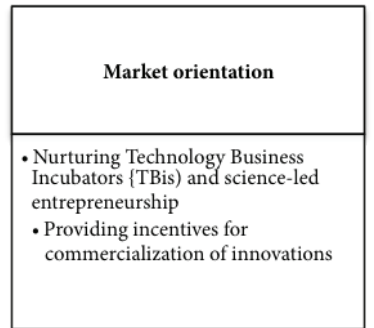

Very interestingly, STIP has also identified the need for supporting STI driven entrepreneurship with viable and highly scalable business models, which are also the main features of the Singaporean model of development (NRF, 2014). However, a lot of research is to be done to identify the actual scenarios in the entrepreneurial domain in India and to make greater impact of these entrepreneurial space in the catch
To further advance this, STIP 2013 also recognizes role of Intellectual Property Rights (IPR). It proposes to put in place a regulatory and legal framework for sharing of IPRs between inventors and investors under which it proposes to modify the regulations for data access and sharing as also for creation and sharing of IPRs.

Discussion on private sector investment in India vis à vis public interventions between 2005 and 2010

Figure 7. Macro-economic comparison between India, China, Brazil and Singapore (a) Private R\&D between 2005 and 2010 (b) Public R\&D between 2005 and 2010 (c) Growth rate Private R\&D (d) Growth rate Public R\&D (e) Share of Public Private in R\&D in 2009-10

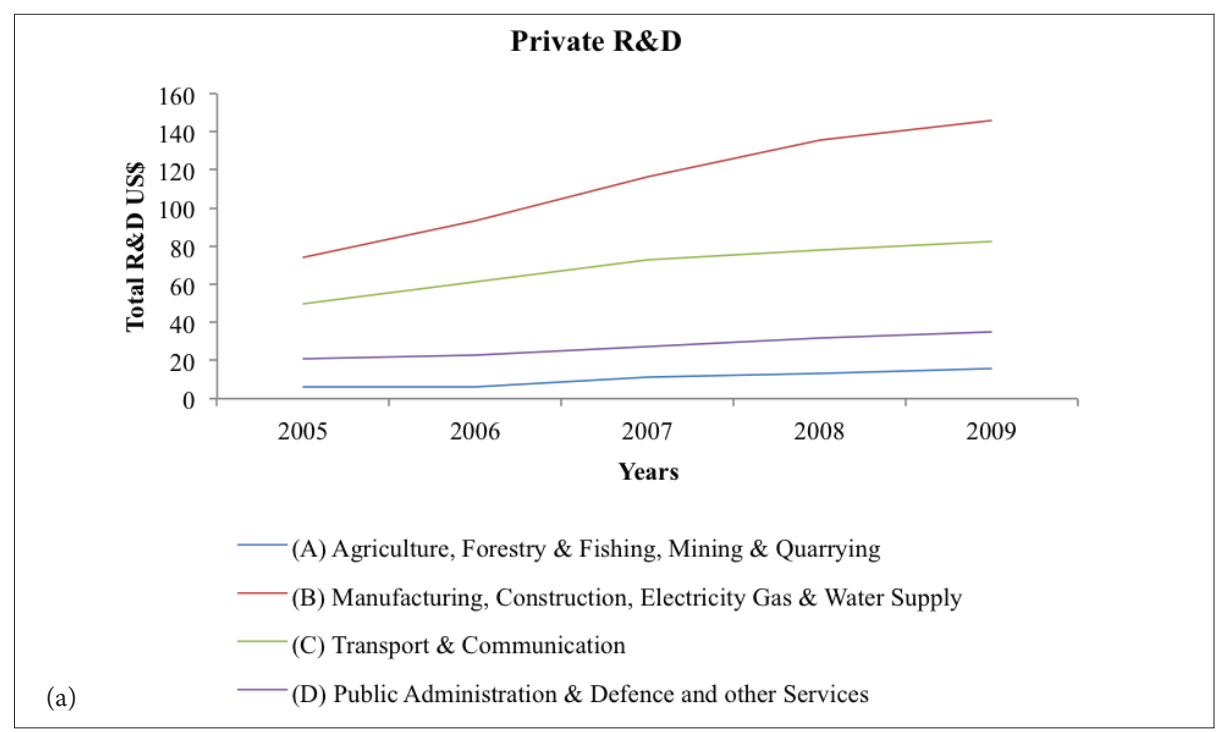

ISSN: 0718-2724. (http://jotmi.org) 

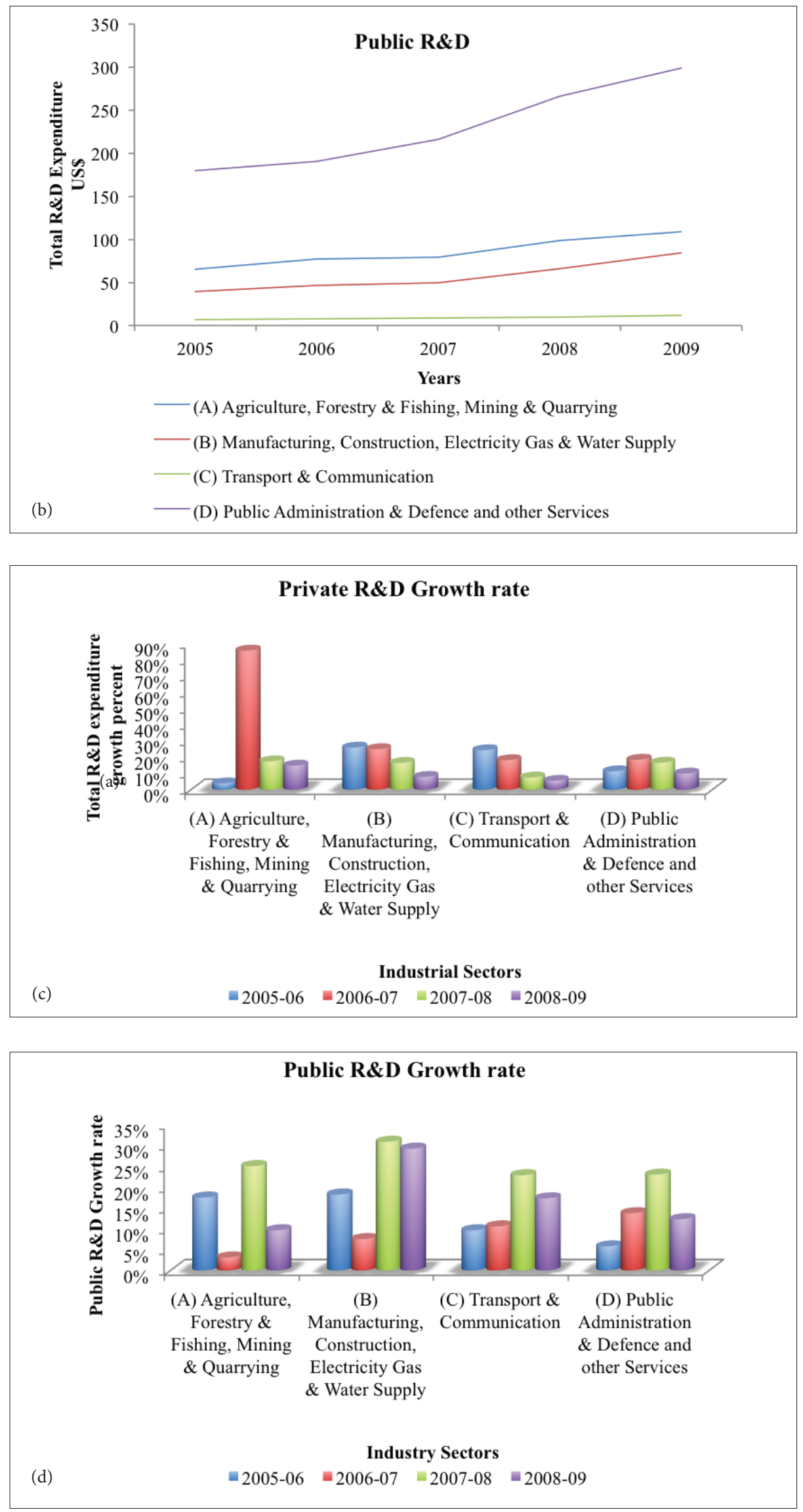


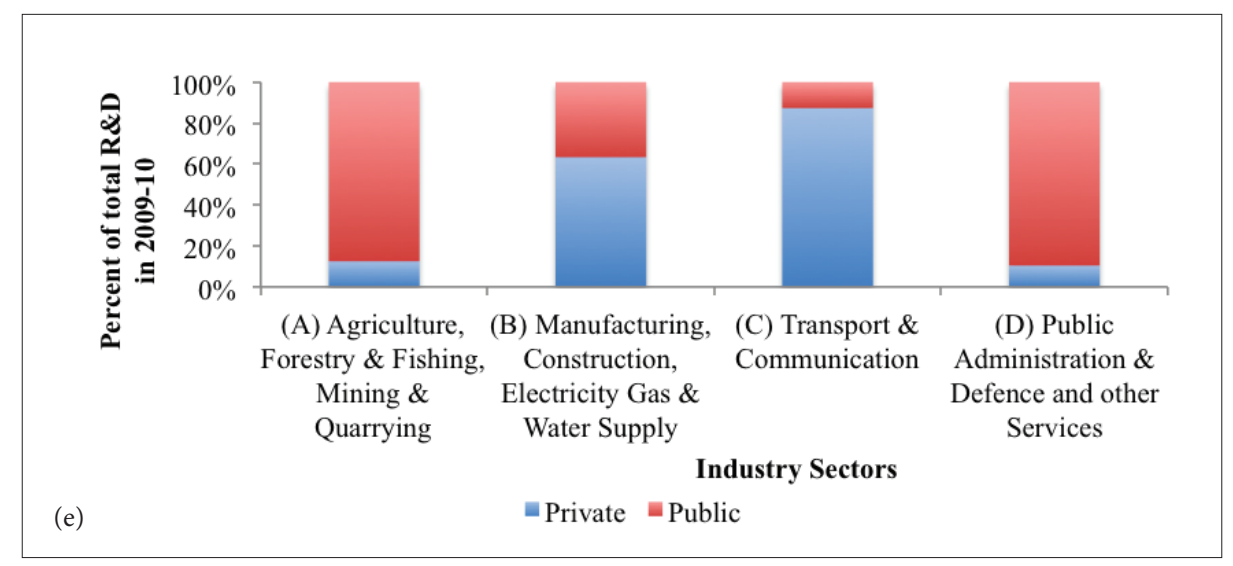

Source: Analysis on Data.gov.in

We observe that $R \& D$ investment has increased for both public and private sectors (Figure 7). However, there is a clear and expected difference in industrial preference for investment by the government and private sector. The public sector spent 60 percent of the total fund in public and defence administration, 22 percent in agricultural allied areas, 15 percent in manufacturing and constructions and the remaining 2 percent in transport and communications. Private sector on the other hand invested 51 percent of the total fund in manufacturing and constructions, next 31 percent in transport and communication, 12 percent in public and defence administration, and the remaining 6 percent in agricultural and allied areas. Similarly we observe that the government is the main stakeholder in the agricultural and defence $\mathrm{R} \& \mathrm{D}$ whereas private sector is mainly concentrated in manufacturing and transport sector. Growth rates are fluctuating for both private and public sector investment across all industries.

The main take away from these data is that it is imperative that policy makers understand the priorities of private $R \& D$ and also the requirement of each company in the industry according to its scale. The paper discusses this issue in the Way Forward in the later sections.

\section{Potential in productivity of India vis. à vis. China, and Singapore $^{6}$}

Total factor productivity has been increasing for China, Singapore and India between the period 1970 and 2013 (Figure 8). While there is a constant observed positive growth for China since 1990, Singapore has gone through negative growth (slow downs) in 5 years since 1990 but the intensity of such negative growth was small. India on the other hand has observed negative growth in three consecutive years from 1997 to 1999 and the decline was as high as 17.1 percent in 1998 .

In 2013, China's total factor productivity was highest at 1.566, while India and Singapore were very close to each other in terms of total factor productivity (India was at 1.246 and Singapore at 1.141). Similar trends are observed in data on labour productivity. China surpassed the labour productivity of both Singapore and India about 1.5 decades ago. In 2013, while China's labour productivity was at 3.214, India and Singapore were 1.554 and 1.314 respectively.

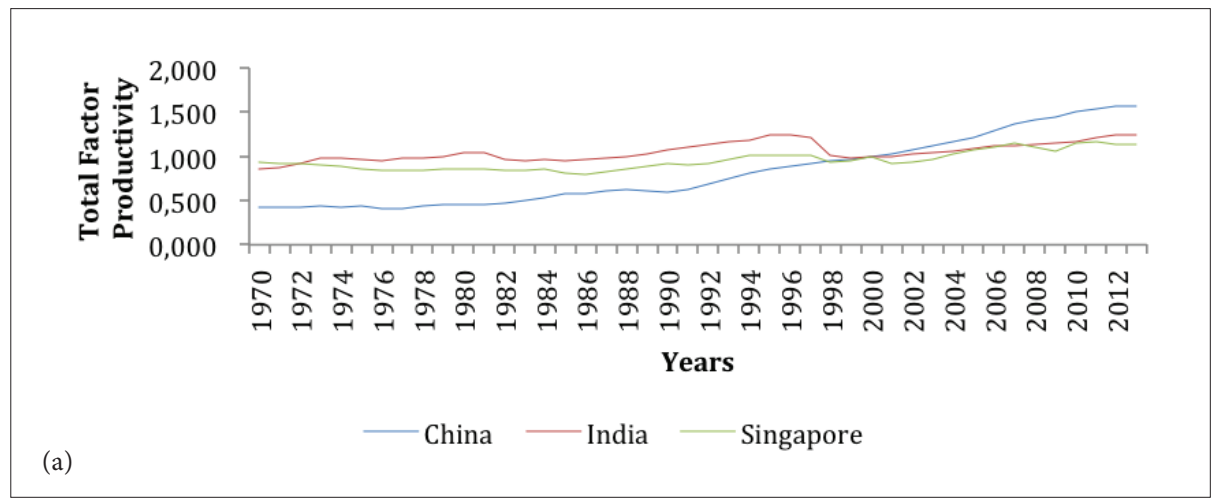

(6) Data for factor and labor productivity is not available for Brazil. 


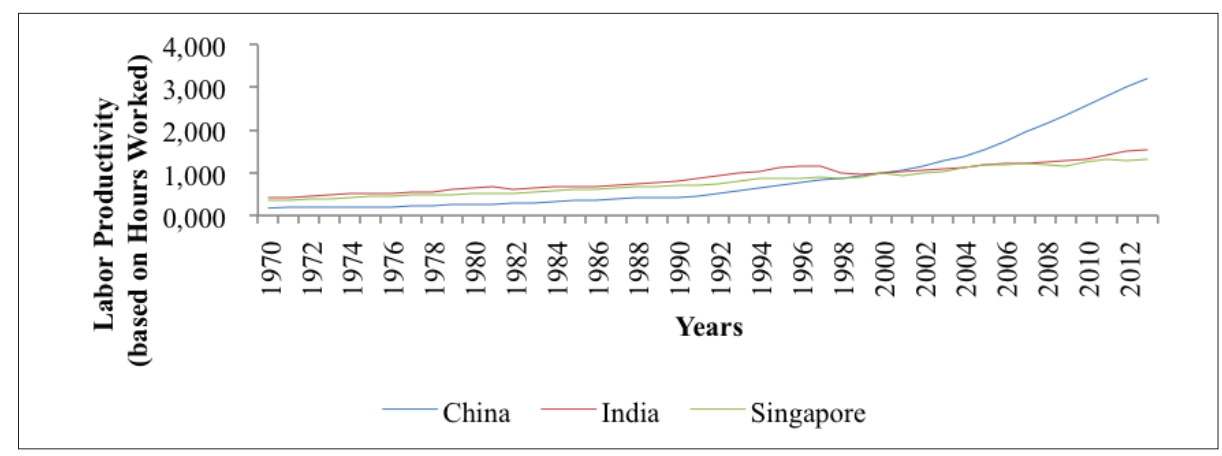

Source: Asian Productivity Organization (APO)

A higher productivity is a positive signal towards boosting the economy. Much can be done by India to match its peer in this regard and these data indicates a lot of good news for India. First, at present India's productivity is more than the Asian Tiger - Singapore, which is known world wide for its success in implementing steep catch-up. Second, the fact that the total factor productivity and labour productivity is high for China; India has a motivation to boost its productivity as one of the major contributors in increasing the rate of catch-up.

\section{Entrepreneurial capabilities of India vis. à vis. China, and Singapore ${ }^{7}$}

To study the entrepreneurial capabilities of India we analyse the data on total early-stage entrepreneurial activity (TEA) by stages of economic development (percent of population aged 18-64) in 2013 and 2014 (Table 3 ). These stages involve nascent entrepreneurship rate, new business ownership rate, early-stage entrepreneurial activity, established business ownership rate and discontinuation of businesses rate and are provided by the Global Entrepreneurship Monitor (GEM). We find that India's stand is the lowest among all four countries with only a 15.82 percent of population aged 18-64 in TEA whereas Singapore has 22.63 percent, China has 41.3 and leading in the group is Brazil with a total score of 48.1. Stages wise as well India has the minimum percent in all the stages except for nascent entrepreneurship rate where it has second lowest percentage of adult population.

This is a greater concern because India has shown a decline in total entrepreneurial activity by 50 percent between 2013 and 2014 when the other three countries have shown positive growth in total entrepreneurial capabilities (Singapore of 1 percent growth, Brazil of 5 percent growth and China of 13 percent growth). While it is arguable that a high total entrepreneurial activity does not necessarily indicates better economic performance as most of the entrepreneurial activity may come from a lack of job opportunities (a situation classified as "necessity driven" by GEM), however it is still a factor towards increasing the job opportunities in the economy and hence require attention of the policy makers.
Table 3. total early-stage entrepreneurial activity (TEA) by stages of economic development (\% of population aged 18-64) in 2014

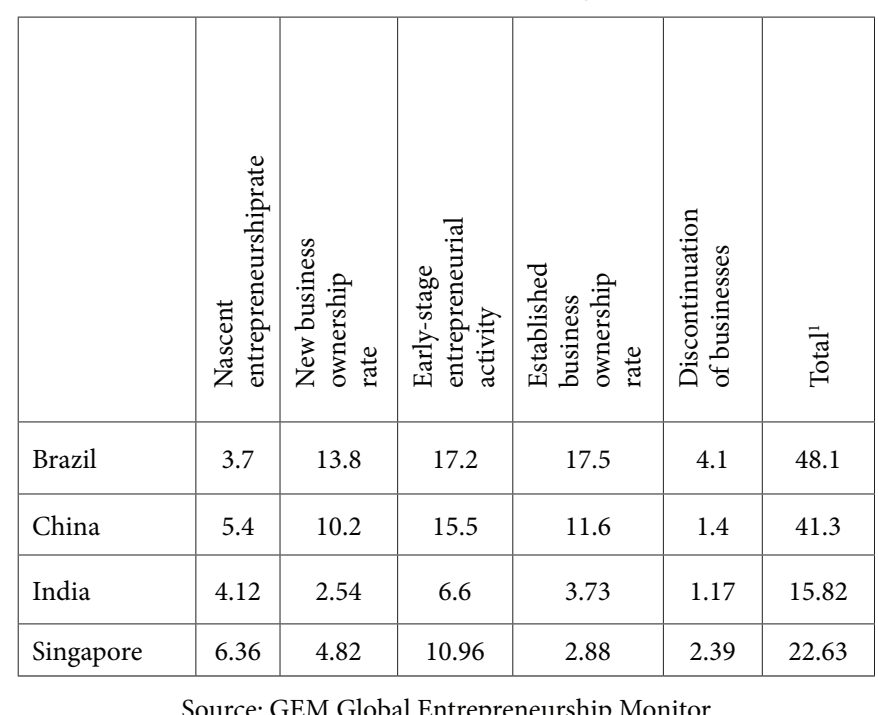

\section{Way forward: An approach towards achievement of objectives specified by STI in India}

\section{a. Government as a venture Capital}

Some of success stories of Science Parks in developed countries such as USA and UK have been very actively adopted by other developing countries across the world. The Science Parks of Silicon Valley in California, Route 128 in Massachusetts (Castells et al., 1994), the Research Park Triangle in North Carolina (Link et al., 2003) and Cambridge in the UK (Koh et al., 2005), are a few of those whose models are being incorporated by Kuwait (Sultan, 1998), Brazil (Cabral et al., 1998), Russia (Kihlgren, 2003), Taiwan (Lai et al., 2005) India (Vaidyanathan, 2007), Israel (Rothschild et al., 2005) and China (Watkins-Mathys et al, 2007 and Ratinho et al., 2010). Creation of Science Park is just one of the steps to target growth, as there is lack of clarity in regarding the performance of Science Parks (Phan et al., 2005).

(7) Data for factor and labor productivity is not available for Brazil.

(8) Total is calculated as Nascent Entrepreneurship Rate + New Business Ownership Rate + Early-Stage Entrepreneurial Activity + Established Business Ownership Rate Discontinuation Of Businesses Rate 
Most economies today place considerable emphasis on entrepreneurship leading to creation of private enterprises as a factor in development and growth of an economy and as a step from simple creation of Science Parks to sustenance of such parks. United Nations University (UNU) has also identified entrepreneurship as a key contributor in growth and employment creation and has highlighted that the impact of entrepreneurial activities will be huge and alike in all the economies advanced, emerging and least developed economies.

However UNU also brings forth that for realization of such an impact, role of the state is important (Naudé, 2011). This is mainly because creation of enterprises requires appropriate skills and initial financial supports. A growing network of institutions called accelerators takes up appropriate skills trainings in entrepreneurial educations, mentoring and investment rapidly (Bliss et al., 2015). Research has shown that successful accelerators can increase the rates of success in new enterprises by 10 to 15 percent. A dominant form of funding that existed in the market is venture capital funds. Research, as early as in 1990, has also shown that venture capital has about two shares in ever three scenarios where funds are raised from private sector sources by new ventures in technology-intensive business in a data sample of 284 technology-based firms founded in New England between 1975 and 1986 (Freear et al., 1990).

Governments such as those of USA and Singapore have channelled their investments in high entrepreneurial potential projects (Wessner, 2008 and NRF, 2014) as this is directly linked to creation of job and wealth (Ratinho et al., 2010); in other words, these governments have taken positions as venture capitalists to enhance states support to increase the chance of survival of new rising technology-based enterprises.

A Venture Capital fund is a medium between investors who seek private equity shares and new enterprises or small and medium size enterprises with strong potential of growth. These investments are characterized by high-risk-high-return opportunities and require expertise in risk assessment. There are different kinds of VC financing which are presented in the

Table 4. While each VC funding enterprise has its own methodology, each of VC enterprise disburses finance in multiple stages and finance is provided in subsequent stages after an analysis of the projects progress and efficient utilizations. VC work closely with managers of fund seeking firm and also hold decision powers through representation on their board of directors (VC, 2003).

Table 4. Types of Venture Capital (VC) Funds

\begin{tabular}{|l|l|}
\hline Types of VC funds & Remarks \\
\hline Early Stage Financing & $\begin{array}{l}\text { This has three sub-divisions seed financing, start up financing and first stage financing } \\
\text { It is given to companies for the purpose of finishing the development of products and services. }\end{array}$ \\
\hline Expansion Financing & $\begin{array}{l}\text { This may be categorized into second-stage financing, bridge financing and third stage financing or mezzanine financing. } \\
\text { It is provided to a company to assist the company expands in a major way. }\end{array}$ \\
\hline $\begin{array}{l}\text { Acquisition or Buyout } \\
\text { Financing }\end{array}$ & $\begin{array}{l}\text { This is categorized into acquisition finance and management or leveraged buyout financing. } \\
\text { It assists a company to acquire certain parts or an entire company. }\end{array}$ \\
\hline
\end{tabular}

Government officials are unlikely to have the expertise or resources to effectively monitor entrepreneurs. However it can always outsource a pool of venture capital investors on an ad-hoc basis and other advisory services to make use of its rich network of growing experts. A directional educational approach to strengthen the work force by incorporating the entrepreneurial aspects in the educational curriculum can be a step in this direction. Similar examples exist in the developed economies of USA and Singapore, GoI can also take initiatives in the same directions. In addition, India's TEA performance also indicates a requirement of government intervention to boost entrepreneurial activities.

\section{Case of USA}

With the objective to enhance technological innovation in new enterprise together with finding means to boost the economy, USA Federal government passed an act called Small Business Innovation Development Act and created a program called Small Business Innovation Research (SBIR) in 1982 (Wessner, 2008). This program is funded by 11 federal agencies, which invest 2.5 percent of their extramural $R \& D$ budget each. The process of development of a program and its commencement is a multiple step process and is described below in Table 5 (Wessner, 2008).
Table 5. Process of program development and its commencement

Identification of research development area

- Parent funding agencies identify key R\&D topics requiring solution

- $\quad$ They solicit request for proposal (RFPs) from interested small business enterprise through public announcement

Selection and grants

- $\quad$ Proposal are selected on a basis of peer reviews of proposals on a competitive basis by experts of appropriate fields

- Best enterprise that meets the requirement and capabilities are awarded contracts or grants

Source: Wessner, 2008

The SBIR program grants the financing in three phases (Wessner, 2008):

- Phase I: In the first phase the program grants as much as US $\$ 100,000$ to undertake a feasibility study and a limited research study at the end of which the enterprise presents scientific idea for commercialization. 
- Phase II: In the second phase the grant value is increased to about US\$750,000 to fund more extensive R\&D to further develop the scientific and commercial promise of research ideas.

.Phase III: When this stage is reached the technology prototype is ready to enter the market space, thus companies do not receive any more SBIR grants and are required to obtain funds from private markets or capital markets. This phase may be difficult for new firms, however agencies have been put in place in support of the new firms.

Empirical analysis on impact of these SBIR programs shows that the mean employment increase and the sales increase were greater for SBIR awardees between 1985 and1995. Quantitatively, it was reported that employment increase by 56 percent and sales increased by 123 percent for the mean SBIR awardee (Lerner, 1996).

\section{Case of Singapore:}

Singapore set up The National Research Foundation (NRF), as early as on 1 January 2006. NRF is the body responsible for policies, plans and strategies for $\mathrm{R} \& \mathrm{D}$, innovation and enterprise (NRF, 2014). NRF launched a National program called National Framework for Research, Innovation and Enterprise (NFIE) to grow innovation and entrepreneurship in Singapore. The main purpose of NFIE is to encourage universities and polytechnics incubate their research into commercial products for the market and assist entrepreneurs to set up technology-based companies. NFIE has rolled out number of grant schemes as support vehicles to achieve its target. These grants schemes are shown in the Figure 9. Clearbridge BioMedics and the CardioLeaf FIT funded under TIS are two of its success stories.

Figure 9. NFIE Schemes

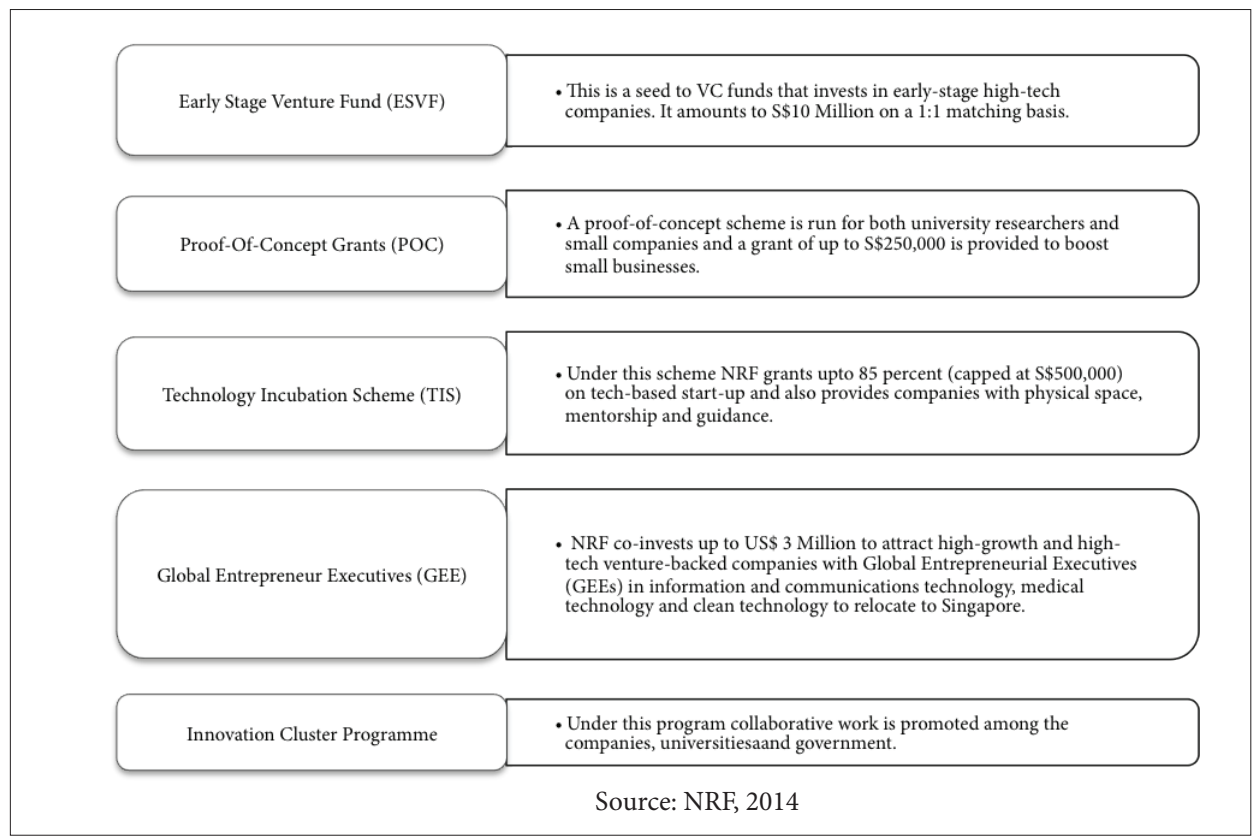

\section{Framework for Government as Venture capitalist - key aspects to be focused}

As noted earlier government officials might lack skills required for managing a venture fund, however it can always pool in experts in VC firms and other advisory services in the public private mode. Key aspects the government should focus on while entering into such ventures in India are as follows.

- Leveraging local scientific and research base: It is imperative that ventures are made in the direction of technological advancement. For this to happen, GoI has to devise a mechanism for identifying marketable research and evaluating the success potential of these existing and on-going research.

- Focusing on short-term investments with shorter turnaround time: An investment of efforts and money for technologies addressing the immediate problem in a sustainable fashion should be encouraged. Researchers and academics should be given incentives to work in the direction of immediate needs.

- Collaborating national capabilities and international capabilities: Platforms should be prepared for association of national research centres and utilization of all the expertise in the area of incubatory technology. At the same time, networking with global platforms to foster research and global principles of business can give a higher thrust to newly incubated small business on the world platforms (Lerner, 2010).

\section{b. Understanding Indian private R\&D level to identify sectors with needs}

STIP 2013 has brought forward the requirement of increasing investment in R\&D. As per the World Bank data from 2011 India invested 
only 0.8 percent of GDP in R\&D expenditure. STIP 2013 has targeted an increase in R\&D expenditure to up to 2 percent of GDP (an increase by 150\%) and has also indicated that major increase can be achieved by involvement of private sector involvement (STIP, 2013).

In order to achieve this objective, it is imperative that actual $\mathrm{R} \& \mathrm{D}$ investment scenario of all the private players and the role of government investment in boosting the morale and confidence of these private players be understood completely. Encouraging private-sector innovation, making public research institutions more accountable and channelling more funds into the most promising R\&D projects are considered important aspect of improving the status of science and technology in even the most advanced countries (Bremer, 2015).

Further, an understanding of each sector's requirement from government intervention will be useful in designing policy instruments. A policy without this understanding is likely to be ineffective because researches have debated over the capabilities of government investment in particular industries in boosting the R\&D investment from the private sector. The most important benefits enjoyed by industries through government investments are as follows (Lee, 2011):

- High (low) technological competence firms enjoy a smaller (greater) tech enhancing effect and greater crowding-out (complementarity) effect of public R\&D support

- Firms operating in industries with high tech opportunities or firms facing more intense market competition have more cost-reducing effect less (more) crowding-out (complementarity) effect of public R\&D support

- Small firms/ with lower sales growth have greater positive effect

The above hypothesis is supported by data provided by World Bank survey - Institutional and Policy Priorities for Industrial Technology Development, in Canada, Japan, Korea, Taiwan, India and China.

Similar studies have also been carried in different countries across the world. For example - a survey financed by the Spanish Ministry of Industry, the Survey on Firm Strategies (Encuesta Sobre Estrategias Empresariales). The survey contains information on firms' total annual R\&D expenditures, which include the sum of internal and external R\&D expenses and the imports of technology (payments for licenses and technical assistance). The data also involves information regarding public $\mathrm{R} \& \mathrm{D}$ funding in the form of subsidies that have contributed to the financing of firms' R\&D activities (González et al. 2007). It is only based on analysis of data in Spain academicians have been successful in establishing that some firms - mainly small and operating in low technology sectors - might not have engaged in $\mathrm{R} \& \mathrm{D}$ activities in the absence of subsidies in Spain.

Considering above results, it is crucial for the GoI to carry out studies to first identify major industries with potential of increasing $R \& D$ investment and to identify which among these industries are likely to show a substitutability (crowding out) ${ }^{8}$ effect towards a government subsidy or grant and which are likely to show a complementarity (crowding in). Further in order to identify the potential of government investment, GoI is required to collect more data in the given context.

\section{c. Entrepreneurship as a part of science curriculum}

Emphasis is being given to promotion of entrepreneurial space in science in Europe and other developed nations. For example, the Entrepreneurship 2020 Action Plan in Europe, which aims to provide education and training, to better entrepreneurial environment and to develop entrepreneurial role models, is under blueprint stage to enhance the European growth dynamics (Entrepreneurship 2020 Action Plan, 2015). India is also realizing the importance of entrepreneurship and is reviewing the draft entrepreneurial policy.

This draft policy highlights that Entrepreneurship Development Cells (EDCs) have been promoted in the engineering and technological colleges. However, only 80 EDCs has been sponsored so far across India. This new policy once implemented will be able to incorporate entrepreneurship as a central component of education. While this policy is giving due attention to much neglected aspects of entrepreneurship, main challenge still remains the time it takes to implement these policy.

Earlier as well, in 2000, the University Grants Commission (UGC) of India emphasized on a curriculum for undergraduate education in entrepreneurship and distributed it to universities and colleges; however, only small number of colleges could actually implement it. Some of the deadlines as documented in the draft policy are over and some are approaching faster (Draft National Entrepreneurship Policy for review 2015). A quicker reaction on the government's part in promoting entrepreneurship can be one key asset in India's development.

\section{Conclusion}

Science, technology and innovations have been central in the growth and development of India in the past few decades. However, India has lagged behind some of its peer countries like China and Brazil and the pace of catch-up still falls behind the pace of these countries as reflected by India's low comparative performance as shown in GDP, GDP per capita, population, fertility rate, mortality rate and life expectancy. India is already placing emphasis on strengthening science, technology and innovation. The efforts are indeed reflected in the high productivity data for both total factor productivity and labour productivity in However, India has lagged behind some of its peer countries like China and Brazil and the pace of catch-up still falls behind the pace of these countries as reflected by India's low comparative performance as shown in GDP, GDP per capita, population, fertility rate, mortality rate and life expectancy. comparison to Singapore. At the same time, it is observed that the entrepreneurial activities in India are on the decline, a situation that is likely to slow down India's catch up process. It indicates a requirement of government intervention

8 A substitutability (crowding out) effect towards a government subsidy or grant means increasing government contribution will decrease industry over all contribution whereas a complementarity (crowding in) effect towards a government subsidy or grant means increasing government contribution will increase industry over all contribution. 
to boost entrepreneurial activities. We bring forth to the attention of the policy makers key tools for implementation of already existing STIP, based on the experiences from across the world. These tools are:

- Making the government as a venture capitalist to support entrepreneurship,

- Making a robust database for all and major aspects of science and innovations to facilitate policy designs and

- Incorporating entrepreneurial as a part of the science curriculum at a faster pace to integrate science and innovation with profitability.

These three factors together constitute the "E for entrepreneurship" and are likely to prove to be an accelerator to the science, technological and innovation led growth and development.

\section{About authors}

\section{Ms. Ragini Chaurasia}

Ms. Ragini Chaurasia is a graduate student in Economics (2014-16) at Sciences Po, Paris and a current intern at the Development Centre, OECD Paris. She pursued her internship at UNESCO Cluster Office in India (covering Bangladesh, Bhutan, India, Maldives, Nepal and Sri Lanka) and worked on the Science, Technology and Innovation Policy of India. Previously, she worked as a Consultant PricewaterhouseCoopers (PwC) Private Limited for two years where she has experience ranging from identification of policy gaps in India vis à vis the world to impact evaluation of social initiatives. She holds a Bachelor of Technology degree from Indian Institute of Technology Delhi (IITD), India.

Dr. Mitrasen Bhikajee

Dr. Mitrasen Bhikajee is a senior program specialist and heads the science sector of the UNESCO Cluster Office in India (covering Bangladesh, Bhutan, India, Maldives, Nepal and Sri Lanka). Prior to this post, Dr. Bhikajee was the Deputy Executive Secretary of the Intergovernmental Oceanographic Commission of UNESCO in Paris (20112014) and the Director of the Mauritius Oceanography Institute (2004-2011). He was Associate Professor at the University of Mauritius and spent fourteen years in marine biology research (1989-2004). He holds a B.Sc. in Zoology, a Master's degree in Fisheries Management and a Ph.D. in Marine Biology.

\section{References}

Bliss, A., \& Nathoo, R. (2015, February 11). Incubators Are Helping Impact Enterprises Grow, But Are They Making a Difference? Retrieved August 17, 2015, from https://www.rockefellerfoundation.org/ blog/incubators-are-helping-impact/

Bremer, C. (2015). Science and technology. Retrieved August 17, 2015, from http://www.oecd.org/science/smarter-research-spendingwould-boost-french-innovation.htm
Dahab, S. \& Cabral, R. (1998). Science parks in developing countries: The case of BIORIO in Brazil. International Journal of Technology Management IJTM, 16(8), 726-726. doi:10.1504/IJTM.1998.002693

Castells, M., \& Hall, P. (1994). Technopoles of the world: The making of twenty-first-century industrial complexes. London: Routledge.

Chandrashekar, S. \& Dayasindhu, N. (2005). Indian remote sensing program: A national system of innovation? Technological Forecasting and Social Change, 72(3), 287-299. doi:10.1016/j.techfore.2004.08.012

Draft National Entrepreneurship Policy For Review. (2015). Retrieved August 17, 2015, from http://ediindia.ac.in/e-policy/

Entrepreneurship 2020 Action Plan. (2015, February 2). Retrieved August 17, 2015, from http://ec.europa.eu/enterprise/policies/sme/ entrepreneurship-2020/index_en.htm

Freear, J., \& Wetzel, W. (1990). Who bankrolls high-tech entrepreneurs? Journal of Business Venturing, 5(2), 77-89. doi:10.1016/08839026(90)90001-A

González, X., \& Pazó, C. (2007). Do public subsidies stimulate private R\&D spending? Research Policy, 37(3), 371-389. doi:10.1016/j. respol.2007.10.009

Kihlgren, A. (2003). Promotion of innovation activity in Russia through the creation of science parks: The case of St. Petersburg (1992-1998). Technovation, 23(1), 65-76. doi:10.1016/S01664972(01)00077-3

Koh, F., Koh, W., \& Tschang, F. (2005). An Analytical Framework for Science Parks and Technology Districts with an Application to Singapore. Journal of Business Venturing, 20(2), 217-239. doi:10.1016/j. jbusvent.2003.12.002

Lai, H., \& Shyu, J. (2005). A comparison of innovation capacity at science parks across the Taiwan Strait: The case of Zhangjiang HighTech Park and Hsinchu Science-based Industrial Park. Technovation, 25(7), 805-813. doi:10.1016/j.technovation.2003.11.004

Lee, C. (2011). The differential effects of public R\&D support on firm R\&D: Theory and evidence from multi-country data. Technovation, 31(5-6), 256-269-256-269. doi:10.1016/j.technovation.2011.01.006

Lerner, J. (1996). The Government as Venture Capitalist: The LongRun Effects of the SBIR Program. Journal of Business, 72 (July 1999), 285-318. doi:10.3386/w5753

Lerner, J. (2010). The future of public efforts to boost entrepreneurship and venture capital. Small Business Economics, 35(3), 255-264. doi:10.1007/s11187-010-9298-Z

Link, A. N., \& Scott, J. T. (2003). The growth of research triangle park. Small Business Economics, 20(2), 167-175. doi: 10.1023/A:1022216116063 
Lucas, R. E. (1988). On the mechanics of economic development. Journal of monetary economics, 22(1), 3-42. doi:10.1016/03043932(88)90168-7

Naudé, W. (2011). Entrepreneurs and economic development. Retrieved August 17, 2015, from http://unu.edu/publications/articles/areentrepreneurial-societies-also-happier.html

NRF (The National Research Foundation). (2014). Retrieved August 17, 2015, from http://www.nrf.gov.sg/about-nrf/national-researchfoundation-singapore\#sthash.Q7UPIsjO.dpuf

OECD Science, Technology and Industry Outlook Policy Database. (2015). Retrieved August 24, 2015, from http://qdd.oecd.org/Table. aspx?Query=574096d0-ff49-441d-9269-fdbe4d0faf05

Phan, P., Siegel, D., \& Wright, M. (2005). Science parks and incubators: Observations, synthesis and future research. Journal of Business Venturing, 20(2), 165-182. doi:10.1016/j.jbusvent.2003.12.001

Blanpied, W. \& Ratchford, J. (2008). Paths To The Future For Science And Technology In China, India And The United States. Technology in Society, 30(3-4), 211-233. doi: 10.1016/j.techsoc.2008.04.006

Henriques, E. \& Ratinho, T. (2010). The role of science parks and business incubators in converging countries: Evidence from Portugal. Technovation, 30(4), 278-290. doi:10.1016/j.technovation.2009.09.002

Reddy, P. (1997). New trends in globalization of corporate R\&D and implications for innovation capability in host countries: A survey from India. World Development, 25(11), 1821-1837. doi: 10.1016/ S0305-750X(97)00079-X

Romer, P. M. (1986). Increasing returns and long-run growth. The journal of political economy, 1002-1037. 94(5), 1002-1037. doi:10.1086/261420

Rongping, M., \& Wan, Q. (2008). The development of science and technology in China: A comparison with India and the United States. Technology in Society, 30(3):319-329. DOI: 10.1016/j.techsoc.2008.04.023

Darr, A. \& Rothschild, L. (2005). Technological Incubators And The Social Construction Of Innovation Networks: An Israeli Case Study. Technovation, 25(1), 59-67. doi:1016/S0166-4972(03)00064-6

Salami, R., \& Soltanzadeh, J. (2012). Comparative Analysis for Science, Technology and Innovation Policy; Lessons Learned from Some Selected Countries (Brazil, India, China, South Korea and South Africa) for Other LdCs Like Iran. Journal of Technology Management \& Innovation, 7(1). doi:10.4067/S0718-27242012000100014
Cruz-Gonzalez, M. Sanchez-Sellero, P., Sanchez-Sellero, M., \& Sanchez-Sellero, F. (2015). Effects of Innovation on Technical Progress in Spanish Manufacturing Firms. Science Technology \& Society, 44-59. doi: $10.1177 / 0971721814561396$

STIP (Science and Technology Policy 2013). (2013). Retrieved August 17, 2015, from http://www.dst.gov.in/stsysindia/stp2013.htm

Sultan, Y. (1998). The concept of science park in the context of Kuwait. International Journal of Technology Management IJTM, 16(8), 800-807. doi:10.1504/IJTM.1998.002699

Vaidyanathan, G. (2007). Technology parks in a developing country: The case of India. The Journal of Technology Transfer, 285-299. doi 10.1007/s10961-007-9041-3

VC (Venture Capital Funds Definition). (2003). Retrieved August 17, 2015, from http://www.investopedia.com/terms/v/vcfund. asp\#ixzz3eQajoGWb

Foster, M. \& Watkins-Mathys, L. (2007). Entrepreneurship: The missing ingredient in China's STIPs? Entrepreneurship \& Regional Development, 18(3), 249-274. doi:10.1080/08985620600593161

Wessner C W, (2008) National Research Council (US) Committee for Capitalizing on Science, Technology, and Innovation: An Assessment of the Small Business Innovation Research Program, 1, Introduction. National Academies Press (US); Retrieved August 17, 2015, from: http://www.ncbi.nlm.nih.gov/books/NBK9599/

He, J., Song, W., \& Zhang, L. (2012). Empirical Research on the Relationship between Scientific Innovation and Economic Growth in Beijing. TI Technology and Investment, 168-173. doi: 10.4236/ ti. 2012.33023

\section{Annexure}

\section{Annexure 1}

Table 6 . Year wise Financial Support in project mode in Research in Science \& Technology, Women Scientists Programs

\begin{tabular}{|c|c|c|c|}
\hline Year & $\begin{array}{c}\text { Number of } \\
\text { projects }\end{array}$ & $\begin{array}{c}\text { Duration of project } \\
\text { (years) }\end{array}$ & $\begin{array}{c}\text { Total budget } \\
\text { (US\$) }\end{array}$ \\
\hline 2008 & 19 & 2 & 220522 \\
\hline 2007 & 42 & 2 & 527750 \\
\hline 2006 & 43 & 2 & 491946 \\
\hline 2005 & 22 & 2.6 & 247799 \\
\hline
\end{tabular}

Source: Department of Science and Technology 
Annexure 2

Table 7. Year wise expenditure in National Science \& Technology Management Information System (NSTMIS)

\begin{tabular}{|c|c|c|c|}
\hline Year & Number of projects & Average duration (years) & Total budget (US\$) \\
\hline 2014 & 20 & 1.5 & 517790 \\
\hline 2013 & 9 & 1.7 & 150297 \\
\hline 2012 & 2 & 2.0 & 103020 \\
\hline 2011 & 4 & 0.6 & 1266321 \\
\hline 2010 & 13 & 1.7 & 178867 \\
\hline 2009 & 8 & 1.4 & 1.42304 \\
\hline 2008 & 5 & 1.9 & 293033 \\
\hline 2007 & 11 & 1.5 & 78067 \\
\hline 2006 & 4 & 1.4 & 138794 \\
\hline 2005 & 5 & 1.8 & 182671 \\
\hline 2004 & 10 & 1.9 & \\
\hline
\end{tabular}

Source: Department of Science and Technology 